\title{
Perception Teachers to Thematic Learning on Curriculum 2013 at Sumber Rahayu OKU Timur Elementary School
}

\author{
Puji Astuti \\ Sekolah Tinggi Ilmu Kesehatan Bina Husada Palembang \\ astuti_fuji22@yahoo.com
}

\begin{abstract}
The teacher as a human resource is directly confronted with the presence of students. Therefore teachers must equip themselves with various competencies, starting from the preparation of learning administration that must be fulfilled and made. Therefore, it is reasonable if a teacher plays an important role in learning in school. Therefore, it is natural that the existence of teachers plays a very important role in carrying out learning in schools. The research objective was to describe the perceptions of low-grade teachers in implementing thematic learning in the curriculum 2013 at Sumber Rahayu OKU Timur Elementary school. This research is qualitative research that contains words to describe the object under study by collecting data first at the time of the research by using documentation and interviews conducted from April to June 2020. The results of this study are the perception of low-grade teachers on thematic learning in the curriculum 2013 is that (1) the existence and accuracy of the preparation of RPP strongly support the success of learning, (2) learning can be done with interesting and fun even though the teacher does not fully understand the curriculum 2013, (3) the existence of facilities and infrastructure owned by the school to support teaching activities are still inadequate, (4) the overall assessment in the 2013 curriculum was felt to be a quite difficult and complicated burdensome teacher. Recommended, it is necessary to prepare an appropriate thematic learning design according to the 2013 curriculum before learning in class.
\end{abstract}

Keywords: teacher perceptions, learning thematic, curriculum 2013

\author{
ENGLISHFRANCA : Academic Journal of English Language and Education \\ Vol. 5, No.1,2021, IAIN Curup \\ P-ISSN2580-3670, E-ISSN2580-3689 \\ DOI: : http://dx.doi.org/10.29240/ef.v5i1.2082, Page 61-78
}




\section{INTRODUCTION}

The process of teaching activities in generally in elementary schools uses the lecture and question and answer method rather than the method of discussion, discovery, and or demonstration. As a result, learning activities in the classroom is teacher-centered and textbooks so that the interactions that occur are only one way, namely the student-teacher and there is no reciprocal vice. This can be due to various reasons, one of which is that the teacher lacks insight into learning renewal or is even familiar with a learning innovation but is reluctant to implement it.

Thematic learning in its implementation requires more on the application of concepts learning by doing. Thus, the existence of a teacher is very important in designing and organizing and creating student learning experiences which can later have an influence on student learning outcomes. This learning experience must be able to show the relationship between concepts so that it can create more meaningful and effective learning. Linking concepts to subjects can produce schemes that make it easier for students accept the lessons presented.

The implementation of the curriculum 2013 requires the readiness of teachers to face changes in learning. Teacher readiness in preparing learning is an important role in success at 2013 curriculum 2013 change, especially during its implementation in class. Therefore, the ability of teachers to learn new learning approaches, strategies, models, and methods is needed so that student competence can be achieved. Apart from the readiness of the teacher, the readiness of students to accept learning changes is also very important in achieving competence. Thematic learning curriculum 2013, notes are needed to observe whether the implementation has been effective. Because not all elementary schools have implemented thematic learning in the 2013 curriculum even though it has been recommended by the government, this is because in its application it needs to be adjusted to the conditions of each school.

Sumber Rahayu OKU Timur Elementary School is one of the elementary schools that has implemented thematic learning Curriculum 2013. Through the initial observations that the author did at Sumber Rahayu OKU Timur Elementary School in March 2020, researchers found several notes that some opinions and responses varied and different perceptions of teachers about the application of thematic learning in elementary schools based on the 2013 curriculum can be started from the preparation of the lesson preparation plans, especially in determining basic competencies, compiling indicators, determining learning media 
and strategies, as well as the readiness and support of infrastructure facilities.

Besides that, Sumber Rahayu OKU Timur Elementary School is located in a village that sometimes has difficulty accessing the internet network. Different understanding of the implementation of the curriculum 2013 does not make the teachers Sumber Rahayu OKU Timur Elementary School do not let go of their hands in preparing lesson plans that must be adapted from curriculum 2013. Although a teacher has to bother preparing the thematic learning tools that are applied. Teachers must also have and understand how the formation of students' abilities in school because it is also influenced by the learning process that occurs in class.

The learning process can be formed based on the ability of the teacher and the teacher's understanding of student characteristics. To create an effective learning process, what the teacher must understand is its function and role in teaching and learning activities, namely as a guide, facilitator, resource person, or information provider. The learning process that occurs depends on the teacher's view of the meaning of learning which will affect the activities of their students, therefore the learning process must pay attention to the suitability of the child's development. To support this, it is necessary to have an understanding of how understand the characteristics of students in the teaching process in the classroom, especially for low-grade students and thematic learning.

Majid (2014) states thematic learning is part of an integrated learning model, namely a learning method that creates students, both individually and in groups, who are active in discovering scientific concepts and understanding scientific principles thoroughly and meaningfully.

This integrated thematic learning needs to be implemented because: (1) in everyday life the subjects stand alone; 2)demands of scientific progress and the existence of information technology; (3) advantages of the thematic learning, the material presented is related to everyday life, can link subjects to one another, and learning is active, effective and fun (Akbar, 2014).

The characteristics that need to be understood from thematic learning according to Hernawan (2011), namely: (1) student centered, role of he teacher as a facilitator is in charge of providing facilities for students to learn; (2) can provide direct experience for students by seeing something real and direct as a basis for understanding things that are abstract; (3) difference between one subject and another becomes unclear, considering that the focus of learning is directed towards getting 
a discussion about material or theme that is closely related to the student's life environment; (4) in the presentation of the concepts of various subjects and which are packaged in a learning process, so that students can understand these concepts as a whole and comprehensively; 5) has a flexible nature, because in implementing it the teacher can link the material from one subject to several other subjects in the form of themes; (6) the student learning outcomes obtained will be able to develop in line with the interests and needs of each student, the opportunity to exploit and optimize the potential of students more widely.

Implementation of the curriculum 2013 in which a teacher plays a very important role, both in preparing lesson plans, to implementation and in evaluating because a teacher is a curriculum planner, implementer, and developer in their class. Each curriculum implementation requires teachers to master the contents of the field of study, understand the characteristics of students, carry out educational and fun learning, and the potential for professionalism and personality development (Mulyasa, 2014).

Referring to the results of research conducted by (Sulih and Jumadi, 2019) on how teachers 'and students' perceptions in learning physics curriculum 2013. The research shows (1) teachers have a good perception by learning physics using a scientific approach, (2) the student's response is very positive towards learning physics using a scientific approach, and (3) has a positive and significant relationship between student perceptions of the application of learning physics using a scientific approach.

By paying attention to this phenomenon, the authors wish to conduct research to obtain more information on how the response of low-grade teachers about how to implement thematic learning curriculum 2013, by the title "Perceptions of Low-Grade Teachers on Thematic Learning in the Curriculum 2013 at Sumber Rahayu Ogan Komering Ulu Timur State Elem, entry School".

\section{THEORETICAL FRAMEWORK Thematic Learning}

In its implementation, the thematic learning process is emphasized on the scientific approach inistry of Education and Culture (2013) aims to provide understanding of knowledge to students to be able to recognize, 
understand the material with a scientific approach, because the various information received comes from various sources and does not depend on unidirectional information from the teacher because during learning and learning process must involve three domains, namely attitudes, knowledge and skills

According to Rusman (2015) thematic learning is an integrated learning model which is a learning system that will be able to provide possibilities for students both individually and in groups to actively explore and be able to find various scientific concepts and principles as a whole. The determination of thematic learning in low-grade primary school learning cannot be separated from the development of the concept of an integrated approach itself. Because basically, thematic learning is the application of integrated learning.

Based on some of the above opinions, the author concludes that thematic learning is learning structured based on certain themes and combines several learning materials from various competency standards and basic competencies of one or several subjects.

Where thematic learning is learning that is centered on student activities so that students are required to always be active learning the concepts of the material being taught. According to Majid (2014) thematic learning has several principles, namely :

1. Holistic, the meaning that the existence of phenomena or events in learning that becomes a study and attention in the thematic learning process is observed and studied from several fields of study or several subjects at once and is not studied from a separate or compartmentalized point of view.

2. Meaningful. The Assessment of a phenomenon from various aspects, which allows the formation of inter-schema relationships that students have, which in turn will have a meaningful impact on the material being studied.

3. Authentic, the meaning in its application learning in thematic form emphasizes to students that students can understand directly about the concepts or principles being learned.

4. Active, means that in its implementation, learning in thematic form is also designed by inquiry discovery because it is where students will be directly involved.

Thematic learning allows students to directly understand the concepts and principles that they want to learn. active in the learning process, from planning, implementation, to the evaluation process 


\section{Strengths and Weaknesses from Thematic Learning Models}

According to Kunandar (2007) thematic learning has the following advantages:

1. It is fun because it starts with students' interests and needs.

2. Providing experiences and in teaching and learning activities relevant to the level of student development and student needs

3. Learning outcomes can be felt by students and can also last a long time because they are more memorable and meaningful.

4. Develop skills in terms of thinking children according to the problem or problem at hand.

5. Cultivate children's skills in socializing through cooperation.

6. Have an attitude of communication tolerance and responsiveness to other people's ideas.

7. Presenting real activities like what students experience and following the problems faced in the students' environment.

Furthermore Trianto (2010), the advantages of implementing thematic learning are as follows:

1. By combines several basic competencies and indicators and subject content so that the material does not occur repetition or accumulation and the material can be arranged coherently.

2. Students can find out that there is a meaningful relationship from the content and learning material because it is more of a means and not an end.

3. The results of learning are intact, making it easy for students to interpret the learning process and receive material that is divided into one theme.

4. Has a combination of subjects, so that students' mastery of the concept will be better and increase?

Thematic learning in addition to having the advantages described above, some disadvantages arise, namely:

1. Demands the role of teachers who have broad knowledge and insight, high creativity, skills, self-confidence and high academic ethos, and are brave enough to package and develop material

2. The development of academic creativity requires good student learning abilities in the aspect of intelligence. This can happen because the thematic learning model that is applied emphasizes how to develop analytic abilities (to give insight), associative abilities (to 
connect), and explorative and elaborative abilities (discover and explore).

3. Thematic learning requires sufficient and useful means and sources of information to develop the necessary insights and knowledge.

4. Thematic learning requires an integrated assessment and measurement system (objects, indicators, and procedures).

5. Thematic learning does not prioritize one or more subjects in the learning process.

The Puskar Team (dalama Rusman, 2015) identified several weaknesses in thematic learning, including:

1. Teacher aspect, teachers must have broad insight, have high integrity, reliable methodological skills, high self-confidence and dare to package and develop material.

2. In the student aspect, thematic learning demands relatively good learning abilities of students, both in academic ability and creativity, because the thematic learning model emphasizes analytical skills, associative abilities, exploratory and elaborative abilities.

3. The importance of the aspects of learning facilities and resources, in their application of thematic learning requires reading materials or sources of information that are quite numerous and varied, even the existence of internet facilities.

4. Curriculum aspects, which must be flexible, oriented towards the achievement of students' comprehension completeness, not on achieving targets for the delivery of subject matter.

5. In the assessment aspect, thematic learning requires a comprehensive assessment method.

6. Aspects of the learning atmosphere are needed because thematic learning tends to prioritize one field of study and the sinking of other fields of study, depending on the educational background.

\section{Understanding Teacher Perception}

Kotler (2000) in Isthofiyani (2014) states that definition of teacher perception is a person's process of interpreting something, choosing, organizing, information, input or opinion, and creating a picture of various problems in the world. Such perceptions can be generated from various aspects but may depend on the presence of physical stimuli of everything but will depend on the relationship between stimuli with the surrounding environment and according to one's condition. 
Mangkunegara (in Arindita, 2002) also argues that teacher perception is a process of giving meaning to the environ ment, in this case, perception includes the interpretation of objects. Receiving the stimulus (Input), organizing the stimulus, and interpreting the stimulus that has been organized by influencing behavior and the formation of attitudes. Hidayat (2013) states that perception is a person's ability to perceive something at issue. Someone can only have perception according to their attitude.

Furthermore, Sondang (2011) emphasized: "perception is a process of structuring and translating a person's impressions about the environment in which he is in". This understanding is also expressed by Veithzal (2006) that "perception is a process taken to organize and interpret their sensory impressions to give meaning to their environment". Perception is a significant psychological factor that contributes to a person's behavior. In looking at the same object or event, the understanding that other people perceive may differ. The surrounding objects that we perceive with our senses are then projected to certain parts of the brain so that we can observe these objects.

The term perception is often referred to as assumptions, images, and views because in perception there is a person's response to a certain thing or object. In general, perception has many meanings. From the description of the opinion of several experts that perception is a process that is preceded by sensing, namely a process that takes the form of receiving a stimulus by someone through the senses or also called the sensory process.

The perception referred to here is that each different individual has a desire to give meaning and see the same thing in different ways so that they give different interpretations of what they see or experience. Thus, in essence, perception is the process of giving meaning by a person to a certain object which is influenced by knowledge, experience, mood, and also desires. The meaning that a person gives to an object can be known through the impressions, opinions, and behavior that are displayed concerning the object in question. In general, perception can be interpreted as one of the psychological aspects that are important to human life in responding to the presence of various aspects or elements and symptoms around it. 


\section{Characteristics of Learning in Low Classes}

The characteristics of learning in the lower classes are concrete learning. This learning process must be designed by the teacher so that student abilities, teaching materials, learning processes, and assessment systems are in depending at the level of development that students have, besides that implementation of the process teaching activities classroom must be developed interactively.

Some of the characteristics of low-grade students according to Djamarah (2008) include: 1) there is a high positive correlation between the health state of physical growth and school achievement, 2) there is an attitude that tends to obey traditional game rules, 3) there is a tendency to praise himself, 4) likes to compare himself with other children, if it is considered advantageous to underestimate other children, 5) if you cannot solve a problem, then it is considered not important. When viewed from Djamarah's statement above, the age of low-grade students still tends to be innocent. Plain here means that students still need guidance to direct what is good and what is bad. Therefore, it is necessary to supervise and control student learning activities at school and home.

Low-grade learning is carried out based on lesson plans that have been developed by teachers. Implementing the learning process. Teachers must be designed by the teacher so that students' abilities, teaching materials, learning processes, and assessment systems are because it must be based on the stages of student development during the learning process. Another thing that must be understood is that the learning process must be developed interactively. In this case, a teacher has a very important role in creating a response stimulus so that students are aware of events in their environment. Low-grade students still need a lot of attention because the focus of concentration is still lacking, attention to speed and learning activities is also lacking. This requires teacher persistence in creating a more attractive and effective learning process.

\section{Implementation Curriculum 2013}

The implementation of the 2013 curriculum is a follow-up step to developing existing curricula, namely the competency-based curriculum, which was initiated in 2004, and the 2006 KTSP which includes competency such as attitude competency, knowledge competency, and skills competency which are integrated with each other (Mulyasa, 2013). 
Curriculum 2013 is carried out to prepare the Indonesian people, especially students who can live life as individuals and citizens who have good qualities, are still productive, very creative, innovative, and effective and can contribute in carrying out the life of a state and world civilization. So that the existence of curriculum development in 2013 only focuses on the formation of competence and character of students, which can be in the form of knowledge and skills and attitudes that can be shown by students as a form of their understanding of these concepts students learn conceptually.

According to Law Number 20 of 2003 concerning the National Education System Article 1 point 19, the definition of curriculum is a set of learning plans and arrangements regarding objectives, content, and learning materials as well as methods used as the basis for guidelines for implementing learning process activities to achieve educational goals. The curriculum is usually distinguished between the curriculum as a written plan, namely the curriculum document and the curriculum as functional, the curriculum that is operated in the classroom is a functional curriculum (Syaodih, 2009).

Implementation is a process of application, which includes brave, have a concept and able to implement policies, and have to innovate that are packaged in practical actions to have an impact, change of knowledge changes change in proficiency, and changes values and attitudes. Implementation of the curriculum in learning can be interpreted as the actualization of the written curriculum in the form of learning (Kunandar, 2007).

In implementing the curriculum (Imas and Berlin, 2014), several factors are expected to help teachers in dealing with student learning difficulties, as follows:

1. Formulation of goals.

2. Identification of sources, including sources of readability, audiovisual sources, human, community, and school sources concerned.

3. Role of related parties

4. Development of workforce professional skills related to implementation.

5. Scheduling activities of Support elements, such as work methods, people, equipment, costs, and time.

6. Effective communication

7. Monitoring. Recording and reporting that helps monitoring 
8. The evaluation process contains objectives, functions, evaluation methods, and evaluation forms.

9. Repair and redesign curriculum.

\section{Thematic Learning Assessment Curriculum 2013}

In the implementation of the 2013 curriculum, there is an educational assessment component which is a the process of obtaining knowledge and processing methods of information that will be used to measure the achievement of student learning outcomes which include various assessments such as authentic, self, portfolio-based, tests, daily tests, midterm tests, final semester tests, competency level exams, competency examinations quality level, national examinations, and taking school / madrasah exams (Permendikbud Number 66, 2013).

According to (the National Education Standards Agency) one of the principles of assessment is to have a comprehensive and mutually integrated learning process. Comprehensive in the sense of an act of assessing student learning outcomes must meet and contain several competency specifications to be assessed and must contain abilities in the cognitive, affective, and psychomotor domains.

Integrated assessment is an assessment that in assessing learning activities must pay attention to cognitive, affective, and psychomotor aspects, so that the results of the assessment are not biased where students complete learning in certain lessons, but also do it during the learning process (Zainal Arifin, 2012).

The assessment process is assessing which is in the form of superior learning carried out, internalization of the character and formation students competencies later, including how learning goals are realized. In this case, the assessment process is carried out to assess the activity, creativity, and involvement of students in learning, especially mental, emotional and social involvement in the formation of student competencies and student character (Mulyasa, 2013).

\section{RESEARCH METHODOLOGY}

Type of research used is research with a qualitative approach. Sugiyono (2010) states in qualitative researchers, the main instrument is humans, who has a role and function in determining the direction of focused research, determining informants for data sources, collecting and assessing data quality, as well as analyzing and interpreting data, then making conclusions on the research findings. 
The reason the researcher used a qualitative approach because, the resulting data is shaped descriptive, the form of documents and words that can be trusted. The type of research used is descriptive research, where this researcher is intended to obtain in-depth information regarding the perceptions of low-grade teachers to thematic learning in the 2013 curriculum at Sumber Rahayu OKU Timur Elementary School from April to June 2020. The data source uses primary data and also use secondary data.

The implementation of research in data collection using observation, interview, and documentation techniques. Sugiyono (2015) said that qualitative research is a human instrument, which has a function in determining what is the focus of research, in selecting informants as data sources, in collecting data, and assessing how the quality of the data is, and also in analyzing data, interpreting data and making conclusions on his findings.

Observation technique using the form of non-participant. Where, author does not participate directly in the learning process and only observes the learning activities carried out by the teacher in the classroom. Researchers also used the interview method where a method of collecting data by asking someone who is an informant or respondent. This is so that the conversation in the interview is more focused and focused on the intended purpose and avoids the conversation that is too broad.

In addition, it is also used as a general benchmark and can be developed by researchers through questions that arise during the interview (Arikunto, 2002). The type of interview conducted in this study was a free guided interview in which the interviewer had brought guidelines about what to ask in general.

Through the documentation method, researchers dig up data such as documents related to thematic learning in low classes, as follows: curriculum, syllabus, lesson plans, assessment documents, learning reference books, schedule of learning activities, lists of teacher names, facilities, and infrastructure, and documentary photos. The researcher as a human instrument made observations on the application about learning thematic curriculum 2013 at lower classes at Sumber Rahayu OKU Timur Elementary School.

Moleong (2011) describes humans as research instruments because humans are planners, the implementer of data collectors, analyzes, interpreters of data, and ultimately reports on research results. The data 
validity test used was a triangulation of sources and techniques. Sugiyono (2015) explains that the validity of the source triangulation was carried out to check the data that had been obtained by comparing it with several sources, while the validity of the technical triangulation was carried out to check the data obtained by interview, observation, and documentation.

Technical data analysis using; (1) Data collection, this stage is carried out the process and prepares the data for analysis. This step requires materials in the form of transcripts of interview results, material recordings, inputting the data obtained and selected and compile data into different types of data by considering the sources of information previously obtained, (2) data presentation is an analysis in the form of tables or matrices, networks, or diagrams. Presentation of qualitative research data is carried out briefly described, can be in the form of tables or charts and there is a relationship between categories, (3) reduction of the is a study of the form of analysis that works by grouping, classifying, discarding unnecessary data, organizing the data according to the results of the reduction then interpreting the results of the observations into themes, then the data that has been organized and arranged will be easy to understand, (4) Conclude and verify data. The results of the initial conclusions that are interpreted are temporary, then they will be subject to changes if valid evidence is found that supports the subsequent data collection process. The conclusion in qualitative research is the answer in the form of data that answers the problem formulation formulated from the beginning of the study. Schematically, the data collection process can be described as follows:

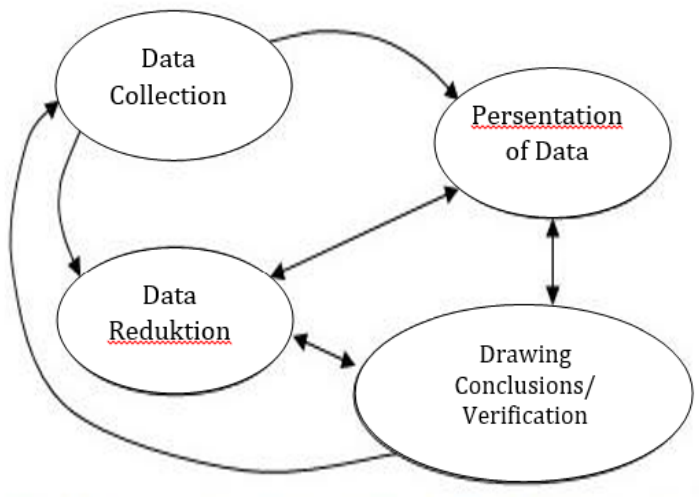

Figure 1.

Interactive Model According to Miles and Saldana(2014) 


\section{FINDINGS \& DISCUSSIONS FINDINGS}

The results of interviews and the results of collecting documentation, as well as observations made by researchers at Sumber Rahayu OKU Elementary School about the perceptions of low-grade teachers in the application of thematic learning in the curriculum 2013, are as follows.

The results of the interviews the researchers conducted with grade 1 , grade 2, and grade 3 teachers had learning tools that were prepared and compiled individually and in consultation with fellow teachers at school. These low-grade teachers also have a syllabus, where the syllabus contains or contains themes, core competencies, subjects, basic competencies, material, time allocation, assessment, learning resources and media, and evaluation.

Regarding the readiness of the learning devices, the three low-grade teachers also have thematic-based learning plans which are based on the syllabus. The detailed content of the lesson plans compiled contains the identity of the subjects which include themes, sub-themes, time allocation, names of subjects, classes/semesters, and time allocation. There are also competencies to be achieved which include competency standards, basic competencies, and indicators. Furthermore, it contains learning objectives that are tailored to the subjects that have been mapped, material according to themes, methods, and learning activities with learning steps including introduction, core activities, and closings. From the learning device, it contains a schedule of learning activities that will be carried out for one semester, preparing curricular books and student assignments, but not all teachers contain an assessment of results containing assessment instruments including performance appraisal and product assessment.

Furthermore, the results of the interview relate to the readiness for the implementation of thematic learning in the curriculum 2013 that has been implemented by grade 1, grade 2 and grade 3 teachers at Sumber Rahayu OKU Timur Elementary School in the implementation of learning ready to make learning interesting and fun despite the obstacles and difficulties in completing the fields in learning tools are sometimes very difficult, for example in choosing media, determining the basic competencies of various subjects and even the indicators.

The learning process in the curriculum 2013 prioritizes practical learning both individually and in groups. Meanwhile, teachers are required to be more active and creative in carrying out teaching, 
especially in low-grade classes. Because, where in thematic learning that is always on the theme of the teacher is required to be able to know the types of learning models and the teacher must also be able to choose and apply learning models properly and pleasantly in accordance with the material presented in the class. However, there are obstacles and difficulties encountered in implementing and implementing them, such as when preparing the learning tools to determine the learning methods and models to be used, because low-grade students still have to be guided and accompanied in learning. In addition, there must be infrastructure and media readiness to support the thematic learning process in accordance with the curriculum 2013.

The principal's response to the implementation of the curriculum 2013 below in implementing to the curriculum 2013 is that the school is ready and trying to fulfill everything that can support the smooth implementation of learning, especially low grade thematic. Teachers also show a good response, even though they have to face and deal with obstacles and obstacles. Starting from the readiness of the teacher, the learning tools, media and methods, and infrastructure that will continue to be homework at Sumber Rahayu OKU Timur Elementary School.

\section{DISCUSSION}

The research findings obtained about the perceptions of low-grade teachers to application of thematic learning curriculum 2013 are shows good. The results of interviews conducted by researchers with grade 1 , grade 2, and Grade 3 teachers, as well as with school principals regarding the perceptions of lower-class teachers on the during the thematic learning process activities according curriculum 2013, are as follows. Based on these learning tools, the teachers of the Sumber Rahayu OKU Timur Elementary School are based on implementing learning. For them, the accuracy in thematic learning that is required in the curriculum 2013 can be carried out properly by low-grade teachers of Sumber Rahayu OKU Timur Elementary School. These teachers can make lower-grade thematic learning more interesting and fun.

The perception of low-grade teachers towards thematic teaching activities in curriculum 2013, that these teachers find it difficult when they have to translate basic competencies into sub-themes and themes into learning. Developing curriculum 2013 thematic learning tools is very important in supporting the successful the learning activity learning itself. The perception of low-grade teachers at Sumber Rahayu OKU Timur Elementary School towards thematic learning in the curriculum 
2013 is that teachers must be able to choose and use various learning media that are tailored to the material to be delivered. Readiness must be supported by the readiness of adequate infrastructure to support the thematic learning process following the curriculum 2013.

From the description of the responses given by the low-grade teachers above, it is in line with what was conveyed by the principal of the Sumber Rahayu OKU Timur Elementary School that related to the readiness of the school to be ready and keep trying and trying to fulfill everything that is can support the smooth implementation of learning, especially thematic learning in the low-class curriculum 2013. Teachers also show a good response, although in practice they must face obstacles and obstacles. Starting from the readiness of the teacher, learning tools, media and methods, and infrastructure. That will be homework for the Sumber Rahayu OKU Timur State Elementary School in the future in implementing the curriculum 2013.

The results above are relevant research that has been done Rusman (2015) entitled "Curriculum Implementation at Elementary Schools A Study on 'Best Practices' Done by Elementary School Teachers in Planning, Implementing, and Evaluating the Curriculum". The results of the study show that the teacher's response during the implementation of the 2013 curriculum was very positive. In the planning of learning activities with a very positive category as well as in planning and evaluation activities in the positive category. The response of elementary school teachers to the implementation of the curriculum 2013 is a good category. In terms of planning, it is included in the very good category, while in the implementation and evaluation activities it is a good category.

\section{CONCLUSION}

From the results of the discussion and research findings through interviews and the results of documentation, as well as observations made by researchers about the perceptions of low-grade teachers of the curriculum 2013 thematic learning at Sumber Rahayu OKU Timur Elementary School, researchers can say that thematic learning which is required in the curriculum 2013 can be carried out properly by low grade teachers of Sumber Rahayu OKU Timur Elementary School. These teachers can make low grade thematic learning more interesting and fun. The three low grade teachers have the same perception of the importance of learning device readiness and find it difficult to translate basic 
competencies into sub-themes and themes into learning. The research conclusions are as follows; (1) Learning can be carried out in a meaningful, interesting and fun way, but teachers still have difficulty determining basic competencies and making indicators of various subjects; (2) The existence and accuracy of the preparation of the lesson plans are very supportive of the success of learning; (3) Schools need infrastructure, learning resources, and learning media readiness to support the thematic learning process in accordance with the curriculum 2013.

\section{REFERENCES}

Akbar, Sa'dun. (2014). Penyegaran Pembelajaran Tematik Berbasis KKNI Kurikulum 2013: Makalah Kuliah Umum. Malang: Universitas Kanjuruhan Malang.

Arikunto, Suharsini. (2002). Prosedur Penelitian Suatu Pendekatan Praktek. Jakarta: PT. Rineka Cipta, Cet. XII.

Djamarah, Syaiful Bahri. (2008). Psikologi Belajar. Jakarta: PT Rineka Cipta.

E. Mulyasa. (2014). Guru dalam Implementasi Kurikulum 2013. Bandung: Remaja Rosda Karya.

E. Mulyasa. (2013). Pengembangan dan Implementasi Kurikulum 2013. Bandung: PT Remaja Rosda Karya.

Hermawan, Asep Herry. (2011). Pengembangan Model Pembelajaran

Tematik di Kelas Awal Sekolah Dasar. Bandung: Modul Jurusan Kurikulum dan Teknologi Pendidikan FIP UPI.

Imas Kurniasih dan Berlin Sani. (2014). Sukses Mengimplementasikan Kurikulum 2013 Memahami Berbagai Aspek dalam Kurikulum 2013. Jakarta: Kata Pena.

Kunandar. (2007). Guru Profesional Implementasi Kurikulum Tingkat Satuan Pendidikan (KTSP) dan Sukses Dalam Sertifikasi Guru. Jakarta: Raja Grafindo Persada.

Majid, A. (2014). Pembelajaran Tematik Terpadu. Bandung: Remaja Rosdakarya.

Majid, A. (2014). Strategi Pembelajaran. Bandung: Remaja Rosdakarya.

Miles, M. B, Huberman, A.M, \& Saldana, J. (2014). Qualitative Data Analysis, A Methods Sourcebook. Edition 3. USA: Sage Publications. Terjemahan Tjetjep Rohindi Rohidi, UI-Press. 
Moleong, L. J. (2011). Metodologi Penelitian Kualitatif Edisi Revisi. Bandung: PT. Remaja Rosdakarya.

Permendikbud No. 66 Tahun 2013 tentang Standar Penilaian (Salinan Lampiran).

Rusman. (2015). "Curriculum Implementation at Elementary Schools A Study on 'Best Practices' Done by Elementary School Teachers in Planning, Implementing, and Evaluating the Curriculum". https://files.eric.ed.gov/fulltext/EJ1079108.pdf Skripsi (Online). Universitas Pendidikan Indonesia. (Diakses pada tanggal 20 Juni 2020).

Rusman. (2015). Pembelajaran Tematik Terpadu: Teori, Praktik dan Penilaian. Jakarta: Rajawali Pres.

Sondang P. S. (2011). Manajemen Sumber Daya Manusia. Jakarta: Bumi Aksara.

Sugiyono. (2010). Metode Penelitian Pendidikan Pendekatan Kuantitatif, Kualitatif, dan R\&G. Bandung: Alfabeta.

Sugiyono. (2015). Metode Penelitian Kombinasi (Mix Methods). Bandung: Alfabeta.

Suluh, M \& Jumadi. (2019). Persepsi Guru dan Peserta Didik terhadap Proses Pembelajaran Fisika Berdasarkan Kurikulum 2013. Jurnal Penelitian dan Pengkajian Ilmu Pendidikan: e-Saintika, Volume 2 Number 2 2019, 62-74.

Syaodih, Nana. (2009). Pengembangan Kurikulum, Teori dan Praktek. Bandung: Remaja Rosdakarya.

Tim Penyusun. (2008). Kamus Besar Bahasa Indonesia. Jakarta: Departemen Pendidikan Nasional dan Balai Pustaka.

Trianto. (2010). Model Pembelajaran Inovatif - Progresif Konsep, Landasan, dan Implementasi pada Kurikulum Tingkat Satuan Pendidikan (KTSP). Jakarta: Kencana.

Undang-Undang Nomor 20 Tahun 2003 tentang Sistem Pendidikan Nasional, Lembaran Negara Republik Indonesia Tahun 2003 Nomor 78.

Veithzal Rivai. (2006). Kepemimpinan dan Perilaku Organisasi. Jakarta: Raja Grafindo Persada.

Zainal Arifin. (2012). Evaluasi Pembelajaran. Bandung: PT. Remaja Rosdakarya. 